\title{
Cassava processing wastewater as a platform for third generation biodiesel
}

\section{production}

\author{
Cristina Neves ${ }^{1}$, Mariana Manzoni Maroneze ${ }^{1}$, Aline Meireles dos Santos ${ }^{1}$, Erika Cristina Francisco², Roger Wagner ${ }^{1}$, Leila Queiroz \\ Zepka $^{1}$, Eduardo Jacob-Lopes ${ }^{1 *}$
}

\author{
${ }^{1}$ Federal University of Santa Maria - Dept. of Food Science \\ and Technology, Av. Roraima, 1000 - 97105-900 - Santa \\ Maria, RS - Brazil. \\ 2University of Passo Fundo/FEAR, Rod. BR 285 - 99052- \\ 900 - Passo Fundo, RS - Brazil. \\ *Corresponding author <jacoblopes@pq.cnpq.br>
}

Edited by: Julio Cesar Pascale Palhares

Received July 24, 2015

Accepted October 09, 2015
ABSTRACT: This study aimed to evaluate third generation biodiesel production by microalgae Phormidium autumnale using cassava processing wastewater as a platform. Experiments were performed in a heterotrophic bubble column bioreactor. The study focused on the evaluation of the bioreactor (batch and fed-batch) of different operational modes and the analysis of biofuel quality. Results indicate that fed-batch cultivations improved system performance, elevating biomass and oil productions to $12.0 \mathrm{~g} \mathrm{~L}^{-1}$ and $1.19 \mathrm{~g} \mathrm{~L}^{-1}$, respectively. The composition of this oil is predominantly saturated (60\%) and monounsaturated (39\%), resulting in a biodiesel that complys with U.S., European and Brazilian standards. The technological route developed indicates potential for sustainable production of bulk oil and biodiesel, through the minimization of water and chemical demands required to support such a process.

Keywords: microalgae, cyanobacteria, agroindustrial wastewater, biofuel

\section{Introduction}

Increasing greenhouse gas emissions and declining fossil fuel resources are the major driving forces behind the search for sustainable renewable biofuels (Zhou et al., 2014). In this context, process integration has emerged as a way to allow for sustainable manufacturing in industrial processing (Friedler, 2010). This approach has been defined as a set of methodologies that combine several process elements to reduce energy consumption and environmental pollution (Porzio et al., 2014).

Among the most common biofuels, biodiesel is an attractive option due to its high energy density, low NOx and SOx emission after combustion, and its compatibility with existing vehicle engines (Rashid et al., 2014). Biofuels derived from microalgae are promising alternatives as third generation biofuels due to the unique characteristics inherent in algae, such as fast proliferation, high oil accumulation, low water consumption rates and feasibility of growing on non-arable lands (Huang et al., 2015).

In addition, microalgae are considered to have the potential to be used as biocatalysts in an integrated bioprocess (Charpentier, 2005). According to Maroneze et al. (2014), these features enable the use of agro-industrial waste as a carbon source, making it economically feasible while contributing to agroindustrial waste management.

Brazil is one of the largest global producers of cassava, whose processing to produce flour and starch gives rise to about 250-300 L wastewater per ton of processed cassava (FAO, 2001). This waste is mainly composed of organic matter and nutrients, and, furthermore, exhibits low levels of toxic compounds or microalgae growth inhibitors (Damasceno et al., 2003). It makes the cassava processing industry a potential platform for microalgaebased processes (Subhadra and Edwards, 2011).
Phormidium is a genus of filamentous, unbranched cyanobacteria, with filaments with a min diameter of 3-4 $\mu$. Several species are known to live in extreme environments such as thermal springs, desert soils and polluted sites, which makes them robust and have simple nutritional requirements (Guiry and Guiry, 2015).

In this regard, this study aimed to evaluate third generation biodiesel production by microalgae Phormidium autumnale using cassava processing wastewater as a platform. The study focused on both the evaluation of different operational modes of a bioreactor (batch and fed-batch) and the analysis of biofuel quality.

\section{Materials and Methods}

\section{Microorganisms and culture media}

Axenic cultures of Phormidium autumnale were originally isolated from the Cuatro Cienegas desert $\left(26^{\circ} 59^{\prime} \mathrm{N}\right.$, $102^{\circ} 03^{\prime} \mathrm{W}$ - Mexico). Stock cultures were propagated and maintained in solidified agar-agar $\left(20 \mathrm{~g} \mathrm{~L}^{-1}\right)$ containing synthetic Braun-Grunow medium (BG11) (Rippka et al., 1979) with the following composition $\left(\mathrm{mg} \mathrm{L}^{-1}\right): \mathrm{K}_{2} \mathrm{HPO}_{4}$ (30), $\mathrm{MgSO}_{4}(75), \mathrm{CaCl}_{2} \cdot 2 \mathrm{H}_{2} \mathrm{O}$ (36), ammonium citrate and iron (0.6), $\mathrm{Na}_{2} \mathrm{EDTA}(1), \mathrm{NaCl}(0.72), \mathrm{NaNO}_{3}(15)$, citric acid (0.6), $\mathrm{Na}_{2} \mathrm{CO}_{3}(1500)$, trace metals $\left[\mathrm{H}_{3} \mathrm{BO}_{3}(2.8)\right.$, $\mathrm{MnCl}_{2} \cdot 4 \mathrm{H}_{2} \mathrm{O}(1.8), \quad \mathrm{ZnSO}_{4} \cdot 7 \mathrm{H}_{2} \mathrm{O}(0.22), \mathrm{Na}_{2} \mathrm{MoO}_{4} \cdot 2 \mathrm{H}_{2} \mathrm{O}$ (0.39), $\mathrm{CoSO}_{4} \cdot 6 \mathrm{H}_{2} \mathrm{O}(0.04)$. The incubation conditions prevailing were a temperature of $20^{\circ} \mathrm{C}$, a photon flux density of $15 \mu \mathrm{mol} \mathrm{m} \mathrm{m}^{-2} \mathrm{~s}^{-1}$ and a photoperiod of $12 \mathrm{~h}$.

\section{Wastewater}

Cassava wastewater from the flour industry (Garça, SP, Brazil) was used as a culture medium. Wastewater was collected on a monthly basis from the discharge point of the hydraulic pressing step (de-watering) for 12 months. Analyses for $\mathrm{pH}$, chemical oxygen demand (COD), total nitrogen (N-TKN), total phosphorus $\left(\mathrm{P}^{-} \mathrm{PO}_{4}{ }^{-3}\right)$, total solids 
(TS), suspended solids (SS) and volatile solids (VS) were performed following the Standard Methods for Examination of Water and Wastewater (APHA, 2005). The results are shown in Table 1 . The carbon/nitrogen ratio $(\mathrm{C} / \mathrm{N})$ and the nitrogen/phosphorous ratio $(\mathrm{N} / \mathrm{P})$ were calculated through COD, N-TKN and $\mathrm{P}_{-} \mathrm{PO}_{4}^{-3}$ and adjusted with wastewater dilution in distilled water and ammonium nitrate to obtain the $\mathrm{C} / \mathrm{N}$ ratio required.

\section{Bioreactor}

Measurements were taken in a bubble column bioreactor. The system was made of borosilicate glass and had an external diameter of $12.5 \mathrm{~cm}$ and a height of 16 $\mathrm{cm}$, resulting in a height/diameter (h/D) ratio equal to 1.28 and a nominal working volume of $2.0 \mathrm{~L}$. The dispersion system of the reactor consisted of a $2.5 \mathrm{~cm}$ diameter air diffuser located inside the bioreactor. The airflow was monitored by a flow meter and the inlet of air and outlet of gases were filtered through filtering units made up of a polypropylene membrane with a pore diameter of $0.22 \mu \mathrm{m}$ and total diameter of $50 \mathrm{~mm}$. Two operational modes (batch and fed-batch) were considered in the experiments.

For batch cultivations, the bioreactor was fed with $2.0 \mathrm{~L}$ of previously sterilized cassava processing wastewater $\left(15 \mathrm{psi} / 121^{\circ} \mathrm{C}\right)$. The experimental conditions were as follows: initial cell concentration of $0.1 \mathrm{~g} \mathrm{~L}^{-1}$, $\mathrm{pH}$ adjusted to 7.6 , temperature of $30^{\circ} \mathrm{C}, \mathrm{C} / \mathrm{N}$ ratio of 68 (12.0 $\mathrm{g} \mathrm{L}^{-1}$ of organic carbon), constant aeration of 1VVM (volume of air per volume of wastewater per minute), and absence of light.

The same experimental conditions were used in the fed-batch cultivations. For the fed-batch culture, the feeding strategy was based on use of the cassava processing wastewater and cassava starch as carbon sources. The feed was added in pulses, when organic carbon concentration reached $6.0 \mathrm{~g} \mathrm{~L}^{-1}$, with organic carbon content being adjusted to $12.0 \mathrm{~g} \mathrm{~L}^{-1}$. This procedure was repeated until the culture reached a stationary phase.

The experiments were performed twice, and in duplicate for each operational mode. Therefore, kinetic data refer to the mean value of four repetitions.

Table 1 - Composition of cassava processing wastewater.

\begin{tabular}{lc}
\hline Parameter & Value \\
\hline $\mathrm{pH}$ & $5.47 \pm 0.05$ \\
$\mathrm{COD}\left(\mathrm{g} \mathrm{L}^{-1}\right)$ & $24.0 \pm 0.35$ \\
$\mathrm{~N}-\mathrm{TKN}\left(\mathrm{g} \mathrm{L}^{-1}\right)$ & $0.25 \pm 0.01$ \\
$\mathrm{P}-\mathrm{PO}{ }_{4}^{-3}\left(\mathrm{~g} \mathrm{~L}^{-1}\right)$ & $0.16 \pm 0.01$ \\
$\mathrm{TS}\left(\mathrm{g} \mathrm{L}^{-1}\right)$ & $35.40 \pm 0.28$ \\
$\mathrm{SS}\left(\mathrm{g} \mathrm{L}^{-1}\right)$ & $25.31 \pm 0.22$ \\
VS $\left(\mathrm{g} \mathrm{L}^{-1}\right)$ & $10.09 \pm 0.13$ \\
$\mathrm{C} / \mathrm{N}$ & $96.0 \pm 4.24$ \\
$\mathrm{~N} / \mathrm{P}$ & $1.50 \pm 0.07$ \\
\hline
\end{tabular}

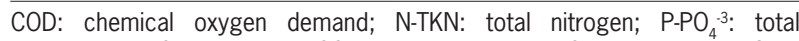
phosphorus; TS: total solids; SS: suspended solids; VS: volatile solids; C/N: carbon/nitrogen ratio; N/P: nitrogen/phosphorus ratio.

\section{Sampling and analytical methods}

Samples of $20 \mathrm{~mL}$ were collected from the bioreactor aseptically in a laminar flow hood every $24 \mathrm{~h}$ during the growth phase of the microorganism. All analyses were performed twice, and in duplicate for each experimental condition.

Cell biomass was gravimetrically evaluated by filtering $10 \mathrm{~mL}$ of culture medium through a $0.45 \mu \mathrm{m}$ membrane filter, drying at $60{ }^{\circ} \mathrm{C}$ until constant weight. Organic carbon concentration was expressed in terms of chemical oxygen demand (COD) and analyzed according to the closed reflux colorimetric method of Standard Methods for the Examination of Water and Wastewater (APHA, 2005). The filtered fraction of the gravimetric procedure was used for the evaluation of organic carbon concentration. At the end of the process, the biomass was separated from the culture medium by decantation, followed by centrifugation, drying and milling.

Total lipid concentration of the biomass was determined gravimetrically by the modified Bligh and Dyer method (1959), using the ratio between methanol, chloroform and distilled water of 2:1:0.8 (v/v/v). The method of Hartman and Lago (1976) was used to saponify and esterify the dried lipid extract to obtain the fatty acid methyl esters (biodiesel). Fatty acid composition was determined using a gas chromatograph. Fatty acid methyl esters were identified by comparison of retention times with the authentic standards and quantified through area normalization by the Chromatography Station T2100p (Plus Edition) v 9.04 software.

The fuel properties of biodiesel (ester content, $\mathrm{EC}$; cetane number, $\mathrm{CN}$; iodine value, II; degree of unsaturation, DU; saponification value, SV; long-chain saturated factor, LCSF; cold filter plugging point, CFPP; cloud point, CP; allylic position equivalents, APE; bisallylic position equivalents, BAPE; oxidation stability, OS; higher heating value, HVV; kinematic viscosity, $\mu$ and kinematic density, $\rho$ ) were determined by the BiodieselAnalyzer ${ }^{\odot} 1.1$ software, which estimates biodiesel properties based on the fatty acid profile of the parent oil, through a system of empirical equations (Talebi et al., 2014).

\section{Results and Discussion}

The performance parameters of the process in different operating modes are shown in Table 2. The fed-batch strategies intensified the conversion of organic carbon into microalgal biomass. Five feeding pulses with cassava processing wastewater improved the performance of the bioreactor, reaching maximum cell densities of $12.0 \mathrm{~g} \mathrm{~L}^{-1}$. In this operational condition, an average rate of organic carbon consumption of $0.105 \mathrm{~g} \mathrm{~L}^{-1} \mathrm{~h}^{-1}$, a biomass yield coefficient of $0.39 \mathrm{~g}_{\text {biomass }} \mathrm{g}_{\text {carbon }}{ }^{-1}$, and a global organic carbon conversion of $78 \%$ were obtained, in a residence time of $336 \mathrm{~h}$ (Figure 1). The discontinuous feeding in the bioreactor 
kept the organic carbon concentration between 6 and $12 \mathrm{~g} \mathrm{~L}^{-1}$, providing cells with sufficient substrate to extend their growth during the cultivation cycle, reducing the restriction to a minimum and increasing biomass yield. This range of organic carbon is associated with the period of the highest volumetric growth rates.

Comparatively, the biomass productions obtained are higher than those reported by Lu et al. (2010) and Vidotti et al. (2014) who reported values of $4.2 \mathrm{~g} \mathrm{~L}^{-1}$ and $3.5 \mathrm{~g} \mathrm{~L}^{-1}$ for $C$. protothecoides and $C$. vulgaris, respectively, in cultivations of cassava processing wastewater. In addition, Bastos et al. (2014) reported maximum cell densities of $0.80 \mathrm{~g} \mathrm{~L}^{-1}$ in the cultivation of cyanobacteria $A$. microscopica Nägeli in rice processing wastewater.

In terms of bulk oil production, the feed-batch strategies reduced the lipid content of the biomass (9$10 \%)$ in comparison with batch cultivations (14 \%). However, as microalgal oils are intracellular products, the best conditions for oil production have to combine biomass production and lipid content. Thus, lipid productions of $1.19 \mathrm{~g} \mathrm{~L}^{-1}$ were evidenced in feed-batch cultivations with cassava processing wastewater. A faster product formation rate implies higher produc-

Table 2 - Kinetic parameters for the process in different operating modes.

\begin{tabular}{lccc}
\hline Parameter & \multicolumn{3}{c}{ Operational mode } \\
\cline { 2 - 4 } & Batch & $\begin{array}{c}\text { Fed-Batch } \\
\text { (wastewater) }\end{array}$ & $\begin{array}{c}\text { Fed-Batch } \\
\text { (Starch) }\end{array}$ \\
\hline $\mathrm{X}_{\max }\left(\mathrm{g} \mathrm{L}^{-1}\right)$ & $5.2 \pm 0.07$ & $12.0 \pm 0.02$ & $8.2 \pm 0.05$ \\
$\mathrm{r}_{\mathrm{s}}\left(\mathrm{g} \mathrm{L}^{-1} \mathrm{~h}^{-1}\right)$ & $0.102 \pm 0.00$ & $0.105 \pm 0.00$ & $0.098 \pm 0.00$ \\
$\mathrm{Y}_{\mathrm{x} / \mathrm{s}}\left(\mathrm{g} \mathrm{g}^{-1}\right)$ & $0.52 \pm 0.00$ & $0.39 \pm 0.00$ & $0.28 \pm 0.00$ \\
$\mathrm{X}_{(\%)}$ & $66.1 \pm 0.7$ & $78.7 \pm 1.9$ & $73.99 \pm 0.9$ \\
Lipid (\%) & $14.0 \pm 0.4$ & $10.0 \pm 0.2$ & $9.0 \pm 0.1$ \\
$\mathrm{P}_{\mathrm{L}}\left(\mathrm{g} \mathrm{L} \mathrm{L}^{-1}\right)$ & $0.73 \pm 0.00$ & $1.19 \pm 0.01$ & $0.74 \pm 0.01$ \\
RT (h) & $120 \pm 0.00$ & $336 \pm 0.00$ & $360 \pm 0.00$ \\
\hline$X$
\end{tabular}

$\mathrm{X}_{\max }$ : maximum cell density; $r_{s}$ : average rate of organic carbon conversion; $Y_{x / S}$ : biomass yield coefficient; $X$ : global organic carbon conversion; $P_{L}$ : lipid production; RT: residence time.

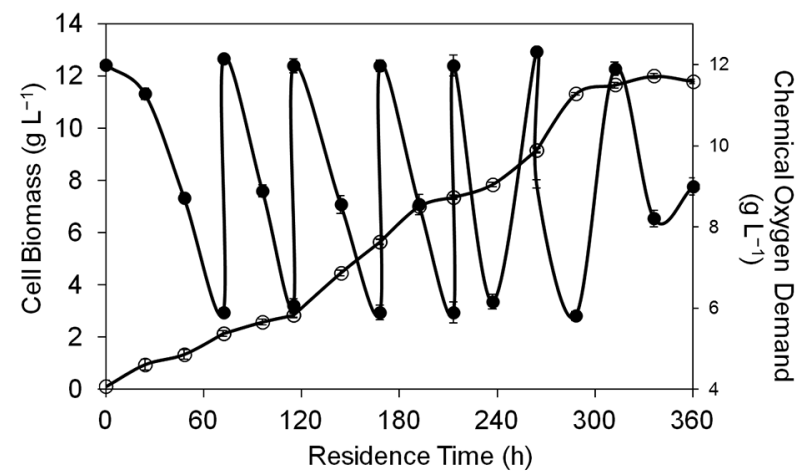

Figure 1- Cell biomass and substrate consumption dynamics in feed-batch cultivations (feeding pulses with cassava processing wastewater). tions and corresponding reductions in plant operating time and operating cost, for an existing plant. By contrast, in order for a new plant to be built, the increase in response rates implies an increase in production, which can be achieved by means of a smaller bioreactor; as a result, less capital investment is required (Roso et al., 2015).

The composition of this oil (Table 3) indicated eight different compounds, with oleic acid (33\%) being the main one. Microalgal oil showed a predominantly saturated $(60 \%)$ and monounsaturated (39 \%) profile. The biodiesel produced from microalgal oils has the following fuel properties (Table 4): ester content of $99 \%$, cetane number of 58.6, iodine value of $36.3 \mathrm{~g} \mathrm{I}_{2} 100 \mathrm{~g}^{-1}$, degree of unsaturation of $39 \%$, saponification value of 266.4 , long-chain saturated factor of $4 \%$, cold filter

Table 3 - Fatty acid profile in fed-batch (wastewater) operational mode.

\begin{tabular}{lc}
\hline Fattyacids & Percent (\%) \\
\hline Caproicacid (C6:0) & $3.80 \pm 0.0$ \\
Caprylicacid (C8:0) & $26.8 \pm 0.3$ \\
Lauricacid (C12:0) & $0.97 \pm 0.0$ \\
Myristicacid (C14:0) & $0.87 \pm 0.0$ \\
Palmiticacid (C16:0) & $20.8 \pm 0.1$ \\
Palmitoleic acid (C16:1) & $5.88 \pm 0.0$ \\
Stearic acid (C18:0) & $6.93 \pm 0.0$ \\
Oleic acid (C18:1n9c) & $33.88 \pm 0.7$ \\
Saturated & 60.1 \\
Monounsaturated & 39.7 \\
\hline
\end{tabular}

Table 4 - Properties of microalgal biodiesel produced in fed-batch (wastewater) operational mode and its comparison with soybean and the standards used in the US (ASTM 6751), Europe (EN 14214) and Brazil (ANP 255).

\begin{tabular}{lccccc}
\hline Properties & Microalgae & Soybean & ANP 255 & ASTM 6751 & EN 14214 \\
\hline EC (\%) & 99.8 & 96.9 & - & - & $\min 96.5$ \\
CN & 58.6 & 49.0 & $\min 45$ & $\min 47$ & $\min 51$ \\
IV $\left(\mathrm{gl}_{2} 100 \mathrm{~g}^{-1}\right)$ & 36.3 & 128 & - & - & $\max 120$ \\
DU $(\%)$ & 39.7 & 143.8 & - & - & - \\
SV & 266.4 & - & - & - & - \\
LCSF $(\%)$ & 5.55 & 1.6 & - & - & - \\
CFPP $\left({ }^{\circ} \mathrm{C}\right)$ & 0.96 & -5.0 & $\max 19$ & - & - \\
CP $\left({ }^{\circ} \mathrm{C}\right)$ & 5.95 & - & - & - & - \\
APE & 33.8 & - & - & - & - \\
BAPE & 0.00 & - & - & - & - \\
OS $(\mathrm{h})$ & 0.00 & 1.3 & - & $\min 3$ & $\min 6$ \\
$\mathrm{HWV}$ & 37.5 & - & - & - & - \\
$\mu\left(\mathrm{mm}^{2} \mathrm{~s}^{-1}\right)$ & 0.90 & 4.2 & - & $1.9-6.0$ & $3.5-5.0$ \\
$\rho\left(\mathrm{g} \mathrm{cm}^{-3}\right)$ & 0.87 & - & - & - & - \\
\hline
\end{tabular}

EC: ester content; CN: cetane number; II: iodine value; DU: degree of unsaturation; SV: saponification value; LCSF: long-chain saturated factor; CFPP: cold filter plugging point; CP: cloud point; APE: allylic position equivalents; BAPE: bis-allylic position equivalents; OS: oxidation stability; HVV: higher heating value; $\mu$ : kinematic viscosity; $\rho$ : kinematic density. ${ }^{a}$ Knothe (2005). 
plugging point at $5.5{ }^{\circ} \mathrm{C}$, cloud point at $0.96{ }^{\circ} \mathrm{C}$, allylic position equivalents of 33.8 , bis-allylic position equivalents of zero, oxidation stability of $0 \mathrm{~h}$, higher heating value of 37.5 , kinematic viscosity of $0.90 \mathrm{~mm}^{2} \mathrm{~s}^{-1}$ and kinematic density of $0.87 \mathrm{~g} \mathrm{~cm}^{-3}$. All these parameters, with the exception of oxidative stability and viscosity, comply with the limits established by U.S., European, and Brazilian standards (ASTM, 2002; UNE-EN, 2003; ANP, 2003), and are comparable to soybean biodiesel (Knothe, 2005). Non-conformities can be circumvented by the addition of antioxidants and additives or the blending of biodiesel with petrodiesel, which improves the quality properties of the biofuel (Hui, 2006; Chu et al., 2013).

Finally, if the values of water, organic carbon, nitrogen and phosphorus are considered, the cassava processing wastewater has a potential value of 12.5 USD $\mathrm{m}^{-3}$, based on equivalents of industrial water, industrial glucose, ammonium nitrate and sodium phosphate (USDA, 2015). These compounds are the feedstocks commonly used for heterotrophic microalgae cultures, demonstrating substantial potential for exploration of this waste to support the production of bulk oil and biodiesel by microalgae.

\section{Conclusion}

Cassava processing wastewater seems a good culture medium for supporting the growth and single-cell oil production of Phormidium autumnale. The high lipid production capacity potential obtained is interesting for the generation of quality biodiesel that meets or surpasses the most stringent US, European and Brazilian fuel standard requirements.

\section{Acknowledgments}

Funding for this research was provided by the Brazilian National Council for Scientific and Technological Development (CNPq).

\section{References}

American Public Health Association [APHA]. 2005. Standard Methods for the Examination of Water and Wastewater. 20ed. APHA, Washington, DC, USA.

American Society for Testing and Materials [ASTM]. 2002. ASTM 6751 - Standard Specification for Biodiesel Fuel (B100) Blend Stock for Distillate Fuels. ASTM, West Conshohocken, PA, USA.

Bastos, R.G.; Bonini, M.A.; Zepka, L.Q.; Jacob-Lopes, E.; Queiroz, M.I. 2014. Treatment of rice parboiling wastewater by cyanobacterium Aphanothece microscopica Nägeli with potential for biomass products. Desalination and Water Treatment 6: 1-7.

Bligh, E.G.; Dyer, J.W. 1959. A rapid method of total lipid extraction and purification. Canadian Journal of Biochemistry and Physiology 37: 911-917.
Charpentier, J.C. 2005. Process intensification by miniaturization. Chemical Engineering \& Technology 107: 3-17.

Chu, J.M.; Xu, X.Q.; Zhang, Y.L. 2013. Production and properties of biodiesel produced from Amygdalus pedunculata Pall. Bioresource Technology 134: 374-376.

Damasceno, S.; Cereda, M.P.; Pastore, G.M.; Oliveira, J.G. 2003. Production of volatile compounds by Geotrichum fragrans using cassava wastewater as substrate. Process Biochemistry 39: 411-414.

European Standard [EN]. 2003. UNE-EN 14214 - Automotive Fuels - Fatty Acid Methyl Esters (FAME) for Diesel Engine Requirements and Test Methods. European Standard, Pilsen, Czech Republic.

Food and Agriculture Organization [FAO]. 2001. An Assessment of the Impact of Cassava Production and Processing on the Environment and Biodiversity. FAO, Rome, Italy.

Friedler, F. 2010. Process integration, modeling and optimization for energy saving and pollution reduction. Applied Thermal Engineering 30: 2270-2280.

Guiry, M.D.; Guiry, G.M. 2015. Algae base: world-wide electronic publication. National University of Ireland, Galway. Available at: http://www.algaebase.org/ [Accessed Jun. 24, 2015]

Hartman, L.; Lago, R.C.A. 1976. Rapid preparation of fatty acids methyl esters. Laboratory Practice 22: 475-476.

Huang, J.; Xia, J.; Jiang, W.; Li, Y.; Li, J. 2015. Biodiesel production from microalgae oil catalyzed by a recombinant lipase. Bioresource Technology 180: 47-53.

Hui, Y.H. 2006. Handbook of Food Science, Technology and Engineering. CRC Press, Boca Raton, FL, USA.

Knothe, G. 2005. Dependence of biodiesel fuel properties on the structure of fatty acid alkyl esters. Fuel Processing Technology 86: 1059-1070.

Lu, Y.; Zhai, Y.; Liu, M.; Wu, Q. 2010. Biodiesel production from algal oil using cassava (Manihot esculenta Crantz) as feedstock. Journal of Applied Phycology 22: 573 . 578.

Maroneze, M.M.; Menezes, C.R.; Barin, J.S.; Queiroz, M.I.; Zepka, L.Q.; Jacob-Lopes, E. 2014. Treatment of cattle-slaughterhouse wastewater and the reuse of sludge for biodiesel production by microalgal heterotrophic bioreactors. Scientia Agricola 71: 521-524.

National Petroleum Agency [ANP]. 2003. ANP 255 - Provisional Brazilian Biodiesel Standard. ANP, Brasília, DF, Brazil.

Porzio, G.F.; Colla,V.; Matarese, N.; Nastasi, G.; Branca, T.A.; Amato, A.; Fornai, B.; Vannucci, M.; Bergamasco, M. 2014. Process integration in energy and carbon intensive industries: an example of exploitation of optimization techniques and decision support. Applied Thermal Engineering 70: 11481155 .

Rashid, N.; Rehman, M.S.U.; Sadiq, M.; Mahmood, T.; Han, J.I. 2014. Current status, issues and developments in microalgae derived biodiesel production. Renewable and Sustainable Energy Reviews 40: 760-778.

Rippka, R.; Derulles, J.; Watrerbury, J.B.; Herdman, M.; Stainer, R.Y. 1979. Generic assignments, strain histories and properties of pure cultures of cyanobacteria. Journal of General Microbiology 111: 1-61. 
Roso, G.R.; Queiroz, M.I.; Streit, N.; Menezes, C.R.; Zepka, L.Q.; Jacob-Lopes, E. 2015. The bioeconomy of microalgal carotenoid-rich oleoresins produced in agroindustrial biorefineries. Journal of Chemical Engineering \& Process Technology 6: 1-7.

Subhadra, B.G.; Edwards, M. 2011. Co-product market analysis and water foot print of simulated commercial algal biorefineries. Applied Energy 88: 3515-3523.

Talebi, A.F.; Tabatabaei, M.; Chisti, Y. 2014. Biodiesel analyzer: a user-friendly software for predicting the properties of prospective biodiesel. Biofuel Research Journal 2: 55-57.

United States Department of Agricultural [USDA]. 2015. Economic Research Service. Available at: http:www.ers.usda. gov// [Accessed Jul. 15, 2015]
Vidotti, A.D.S.; Coelho, R.S.; Franco, L.M.; Franco, T.T. 2014 Miniaturized culture for heterotrophic microalgae using low cost carbon sources as a tool to isolate fast and economical strains. Chemical Engineering Transactions 38: 325-330.

Zhou, W.; Chen, P.; Min, M.; Ma, X.; Wang, J.; Griffith, R.; Hussain, F.; Peng, P.; Xie, Q.; Li, Y.; Shi, J.; Meng, J.; Ruan, R. 2014. Environment-enhancing algal biofuel production using wastewater. Renewable and Sustainable Energy Reviews 36: 256-269. 